\title{
Světová literatura v diskusi
}

\author{
Anton Pokrivčák (Trnava) - Miloš Zelenka (České Budějovice)
}

Marko Juvan: Worlding a Peripheral Literature. Singapore: Palgrave Macmillan, 2019. 297 s. ISBN 978-98132-9404-2.

Triviální fakt, že současný svět se čím dál tím více globalizuje a propojuje, vede k hledání uni- j verzálního v partikulárních projevech jednotlivých kultur. Světová literatura implikuje právě takovouto univerzálnost. Avšak existuje zde i protikladný trend, který je přirozeně nutno vzít do úvahy, protože je dialektickým protikladem toho prvního. Tyto dva momenty, tj. směřování partikularismu národního anebo universalismu světového, jako k definičním momentům konstituování světové literatury, se staly obsahem XXII. mezinárodního kongresu ICLA/AICL v Macau realizovaného na přelomu července a srpna 2019 pod názvem Literature of the World and the Future of Comparative Literature. Kongres se pokusil zmapovat teoretické koncepty světové literatury, které svým pojmoslovným aparátem a sémantikou v poslední době nejvíce ovlivnili zahraniční komparatisté David Damrosch, Franco Moretti a Pascale Casanova. Právě tito badatelé oživili debatu o textech vstupujících do symbolického prostoru „literatury světa“, „světové literatury“, „světovost literatury“, „světový literární systém“ či „světová literární republika“. Jestliže Damrosch ve své monografii What is World Literature? (2003), která středoevropským badatelům může svým názvem, nikoli však koncepcí, připomínat dílo Dionýze Ďurišina Čo je svetová literatúra? (1992), ztělesnil americkou vizi světovosti jako virtuální sít děl přeložených do angličtiny, v podstatě eliptickou refrakci národních literatur, jeho opačnou pozici představuje italský badatel Moretti. Ten navrhuje „distant reading“, tj. porozumění světové literatuře nikoli studiem jednotlivých textů, ale agregováním a analýzou „velkých dat“, které reprezentují nadčasové struktury literárních jevů a procesů.
Obdobně k ideji „světové literární republiky“ jako k virtuální meziliterární síti bez hranic a hodnotových bariér se zase hlásí francouzská komparatistka Pascale Casanova, kritizující koncept univerzální literatury jako ustáleného korpusu textů, překračujících národní politické a lingvistické horizonty.

Do tohoto diskursu, v němž světová literatura ztrácí status fixní kategorie a stává se spíše metodou, vstupuje monografie Marka Juvana Worlding a Peripheral Literature (2019). V sedmi kapitolách autor z nejrůznějších aspektů zvažuje složitý fenomén světové literatury jako ústřední pojem nejen současné komparatistiky, ale celé literární vědy. Monografie je sice sestavena z dříve publikovaných studií uveřejněných v prestižních časopisech (Arcadia, Neohelicon, Canadian Review of Comparative Literature, Comparative Literature and Culture ad.), jejich ediční úprava a podstatné textové doplnění však vytváří dojem kompoziční a tematické celistvosti. Autor se soustředuje na proces, kterým se dílo periférní literatury, v tomto případě slovinské literatury, stává světovým. Celá monografie je v podstatě analýzou fenoménu periférnosti vis a vis centrality evropské literární scény, kterou se autor snaží demonstrovat na slovinském romantickém básníku Prešernovi. V prvním metodologicky koncipovaném Introduction se Juvan zamýšlí nad Goetheho Weltliteratur, která si kladla vedle odkazu na existenci jiných literatur světa za úkol prosadit německou literaturu na mapu evropské literární scény. Světovost se tudíž v souvislosti s Goethem velmi často interpretuje jako „evropskost“, jako europocentrický pohled na globalismus skrze prizma národního zájmu. Národní zájem je v tomto smyslu důležitý, 
protože v souladu s principem extraliterárnosti jako základního determinantu komparativní literatury je zde počin Goetheho vysvětlován i prostřednictvím asymetrie trhových a mocenských vztahů. V následující kapitole The Canonicity of World Literature and National Poets Juvan nesouhlasí s identifikací světové literatury, s tím, co by bylo možné nazvat globální literaturou, protože původní koncept světové literatury implikuje historicitu a specifickou prostorově-časovou šířku, na což se v současnosti zapomíná. Národní básníci jsou v romantismu a v postromantismu vlastně kulturními světci, kteří mohli reprezentovat svou kulturu na mezinárodní úrovni jen potud, pokud byla jejich autorita uznaná ,jinakostí“, kterou v tomto případě reprezentovala vznikající světová literatura. V třetí kapitole Perspectivizing World Literature (in Translation) Juvan poukazuje na známou věc, tj. na důležitost jazyka a významnost země. Jestliže se chce literární dílo stát světovým, musí pocházet $\mathrm{z}$ významné země a být napsané ve světovém jazyce. S tím je samozřejmě spojena ekonomická síla, knižní trh, využití intelektuální práce apod. Badatel vychází z faktu, že světová literatura, at už jako „sít“", nebo „kánon“, tvoří hierarchizovaný systém, do něhož se volně cirkulující texty dostávají prostřednictvím velkých literatur, nejčastěji však prostřednictvím anglicky psané literatury. Světová literatura jako „velký globální narativ“ se tak stává badatelským předmětem ztotožňovaným výlučně $\mathrm{s}$ anglickým jazykem: v podtextu je zřejmá inspirace specifickým modelem ekonomické globalizace, která sice vytváří pomyslnou univerzalitu světové literatury, jejíž „srdce“ či ,jádro“ však klade do mocensky dominantního a jazykově monolitního „centra“, nikoli na bezvýznamnou periferii. Podle Juvana nejde o přitakání nerovnosti mezi jednotlivými literaturami, ale jen o adekvátní reflexi přirozeného začleňování malých středoevropských a jihovýchodoevropských literatur (např. slovinské), do nově vytvářeného světového literárního systému v první polovině 19. století, kdy se formovala národní identita. Prostor světové literatury vznikal přitom paralelně s genezí národních literatur.
Ve zbývajících kapitolách se Juvan věnuje faktu, že kromě kategorií národního a světového existuje vícero forem a stádií, jimiž dílo může procházet na cestě od partikulárního $\mathrm{k}$ univerzálnímu. Transnárodní komparatistika vychází z charakteristiky nadnárodního nejen jako výsledku transferu kulturních, ale i filozofických, ekonomických a jiných faktorů a fenoménů, které jsou determinovány zejména procesem kanonizace. Kanonizovaná díla na národní úrovni přitom často využívají motivy Parnasu, Heliconu, Olympu, jako míst, kde sídlí „bohové“, "světci“ národa, čímž se tyto národní celebrity internacionalizují a zesvětštují. Kromě tematicko-motivického plánu je pro formování národně-světského obrazu literatury důležitý i jazyk jako místo estetizace národních obrazů. Klíčové jsou zde reflexe věnované světovosti ve smyslu "stávající se světovým“ - worlding. Juvan poukazuje, že důraz je zde nikoli na extraliterárním vymezení světové literatury, ale na schopnosti literatury samotné vytvořit svět. Můžeme tu doplnit, že někteří literární teoretici proto mluví spíše než o světové literatuře o "literatuře světa“ (H. Saussy), která se zdá být méně elitářským pojmem a která méně intenzivně implikuje jistou homogenitu a představu standardizovaného kánonu velkých děl. Např. americký komparatista Haun Saussy zdůrazňuje akcent ,jinakosti“ a odmítá se dívat na světovou literaturu jen z jednoho kulturního a teoretického pohledu, jiný amerikanista Jeffrey R. Di Leo formuluje pojem „worlded literature" ve smyslu literatury poznamenané, zasažené světem, tj. literatury propojené přes globální sítě, překlady, migraci apod. Světová literatura se tak sublimuje v literaturu „globálni““ či „zglobalizovanou“, v nový typ politické dominance a kulturní rozmanitosti. Juvan si uvědomuje, že struktura světového literárního systému chápaného historicky a procesuálně je tak založena na hodnotovém protikladu dominantního „centra“ a podřízené "periferie“, kam lze zařadit literatury střední a jihovýchodní Evropy. Ty logicky podléhaly vlivu silnějších hegemonistických center (koloniálních) politické moci na Západě. Z této premisy Juvan vyvozuje, že jejich integrace do světového 
literárního prostoru, byla legitimizována kritérii odvozenými ze západního kánonu.

Podle slovinského badatele je nutné se smíritit s touto, historicky danou „nerovností“, její popírání je mylné, protože reálně neexistuje jiná možnost než respektovat skutečnost, že hodnotové a estetické paradigma světové literatury je třeba přijmout jako přímý důsledek ekonomické a masmediální globalizace. Uvažovat o světové literatuře znamená akceptaci této nerovnosti jako jistého epistemologického rámce a způsobu prezentace, který odráží přirozený protiklad „rozvinutosti“ a „nerozvinutosti“.

Juvanovy reflexe o světové literatuře zároveň otevírají empirickou otázku, jak by měly vypadat ideální dějiny národní literatury na světovém pozadí anebo, jaká by měla být podoba dějin světové literatury logicky zohledňující funkce a vývoj jednotlivých národních celků a regionů? Z tohoto pohledu je zřejmé, že světové literární dějiny oscilující mezi „příběhem“ a „kánonem“ by měly mít podobu hypertextově otevřeného literárního archivu, jakési palimpsestové literární „mapy“, která bude vědomě transkulturní a hyb- ridní a která umožní kombinovat nejrůznější přístupy a interpretace. Přitom však zachová „textualizaci kontextu“ a „kontextualitu textu“, tj. přiměřenou rovnováhu „extrinsic“ a „intrinsic“ momentů na horizontech kulturních a textových řad. Světové literární dějiny by proto neměly vytvářet fiktivní realitu generovanou slovy a významy, nýbrž musejí vystupovat jako živý „synergický“ a dynamicky pulzující organismus schopný samoregulovat procesy své evoluce. Juvanovu metodu můžeme označit za zdravě „konzervativní“, rekonstrukční v tom smyslu, že krizi literární vědy lze objektivně diagnostikovat a že lze dosáhnout obecně přijatelný konsensus v podobě epistemologického a terminologického základu vymezeného soustavou konkrétních principů a pojmů. S monografií nemusíme ve všem souhlasit, zejména s jejím akcentem na sílu ekonomických faktorů a jazykovou dominanci angličtiny. Přesto celkově přináší zásadní teoretický vklad do současných diskusí o podobách, podstatě a funkcích světové literatury, permanentně oscilující v širokém prostoru mezi „národním“ a „univerzálním.“

prof. PhDr. Anton Pokrivčák, PhD.

Katedra anglického jazyka a literatúry

Pedagogická fakulta, Trnavská univerzita

Priemyselná 4, 91843 Trnava, SK

anton.pokrivcak@truni.sk

prof. PhDr. Miloš Zelenka, DrSc.

Katedra slovanských jazyků a literatur

Pedagogická fakulta, Jihočeská univerzita

Jeronýmova 10, 37115 České Budějovice, CZ

zelenka@pf.jcu.cz

Toto dílo Ize užít v souladu s licenčními podmínkami Creative Commons BY-SA 4.0 International (https://creativecommons.org/licenses/by-sa/4.0/legalcode). Uvedené se nevztahuje na díla či prvky (např. obrazovou či fotografickou dokumentaci), které jsou v díle užity na základě smluvní licence nebo výjimky či omezení príslušných práv. 